\title{
Attributing of global evapotranspiration trends based on the Budyko framework
}

Shijie $\mathrm{Li}^{\mathrm{a}}$, Guojie Wang ${ }^{\mathrm{a}}$, Chenxia Zhu', Jiao Lu', Waheed Ullahª, Daniel Fiifi Tawia Hagan ${ }^{\mathrm{a}}$, Giri Kattel $^{\mathrm{a}, \mathrm{b}, \mathrm{c}}$, Jian Peng ${ }^{\mathrm{d}, \mathrm{e}}$

$5{ }^{a}$ Collaborative Innovation Center on Forecast and Evaluation of Meteorological Disasters (CIC-FEMD), School of Geographical Sciences, Nanjing University of Information Science and Technology, Nanjing 210044, China

${ }^{b}$ Water and Agriculture Program (WEAP), Department of Infrastructure Engineering, The University of Melbourne, Melbourne 3010, Australia

${ }^{c}$ Department of Hydraulic Engineering, Tsinghua University, Beijing 100084, China

10 department of Remote Sensing, Helmholtz Centre for Environmental Research-UFZ, Permoserstrasse 15, 04318, Leipzig, Germany

${ }^{\mathrm{e}}$ Remote Sensing Centre for Earth System Research, Leipzig University, Talstr. 35, 04103, Leipzig, Germany

Correspondence to: Guojie Wang (gwang@nuist.edu.cn)

Abstract. Actual evapotranspiration (ET) is an essential variable in the hydrological process, linking the carbon, water, and

energy cycles. Global ET has significantly changed in the warming climate. Although increasing vapour pressure deficit (VPD) due to global warming enhances atmospheric water demand, it remains unclear how the dynamics of ET are affected. In this study, using multiple datasets, we disentangled the relative contributions of precipitation, net radiation, air temperature $\left(\mathrm{T}_{1}\right), \mathrm{VPD}$, and wind speed on affecting annual ET linear trend using an advanced separation method that considers the Budyko framework. It is found that the precipitation variability dominantly controls global ET in the dry climates, the net radiation has substantial control over ET in the tropical regions, and VPD is impacting ET trends in boreal mid-latitude climate. The critical role of VPD in controlling ET trends is particularly emphasized due to its influence in controlling the land-atmosphere interactions.

\section{Introduction}

Actual evapotranspiration (ET) is the condition in which water transforms from liquid to gaseous state. Such transformation

synchronously absorbs energy of the air making ET as the largest terrestrial water flux component accounting for more than $60 \%$ of global precipitation (Trenberth et al., 2007). ET directly affects hydrological processes at both regional and global scales (Zhang et al., 2016) by being a strong linkage between water, energy, and carbon cycles. As a result, ET plays a crucial role in land-atmosphere interactions amongst various climatic variables, including precipitation, air temperature, humidity, solar radiation and wind speed (Koster et al., 2006; Wang et al., 2011; Miralles et al., 2018), which consequently influence the climate at global and regional scales. An accurately estimated ET can therefore make a comprehensive contribution to understand the changes of hydrological cycles and the associated extreme events, such as droughts and floods, as well as their impacts on ecosystem productivity, water-use efficiency, and irrigation needs for agriculture (Sheffield et al., 2012; Sun et al., 2017; Ahmadi et al., 2019; Jalilvand et al., 2019).

However, the available ground ET measurements from traditional methods (e.g. eddy covariance, porometry and lysimeters, and scintillometry) have shortcomings such as sparse observational sites and short time span (Allen et al., 1991; Everson et al., 2009; Monteith et al., 1990). To overcome these limitations, various spatially distributed ET products have been developed and widely used, including those from remote sensing, land surface models, and reanalysis, such as the GLEAM (Global Land Evaporation Amsterdam Model) product and the GLDAS (Global Land Data Assimilation System) (Su et al., 2002; Miralles et al., 2011a, b; Mu et al., 2011; Onogi et al., 2007; Dee et al., 2011; Reichle et al., 2017; Bosilovch et al.,

2017; Haddeland et al., 2011; Schellekens et al., 2017; Jung et al., 2009; Loew et al., 2016; Peng et al., 2020).

Studies of climate warming intensification on global water cycle have indicated the increasing importance of understanding ET changes in space and time (e.g., Allen et al., 2002; Wu et al., 2013; Pan et al., 2015). In recent decades, ET has shown a 
sudden and unusual increasing or decreasing trends across the globe (Miralles et al., 2013; Pascolini-Campbell et al., 2019), so that an accurate attribution of the ET changes is urgently needed. The changing ET over the longer time scale is jointly determined by climatic modes (e.g. El Niño-Southern Oscillation) (Martens et al., 2018; Miralles et al., 2013) and the longterm changes of climatic variables (Pan et al., 2020; Zeng et al., 2016; Rigden et al., 2016; Wang et al., 2011; Zhang et al., 2015). For example, the upward trend of the global ET from 1982 to the late 1990 was attributed to increased radiation and air temperature (Douville et al., 2013; Jung et al., 2010). Similarly, the change of global ET during 1998-2008 was lapsing due to limited soil moisture supply in the Southern Hemisphere and transitions to the El Niño condition (Jung et al., 2010; Miralles et al., 2014). Zhang et al. (2015) demonstrated how the water supply, available energy, and atmospheric water demand jointly affected the global ET changes from 1982 to 2013, which accounted for 49\%, 32\%, and 19\% of global ET changes respectively.

However, different evapotranspiration algorithms, parameterizations, and input climate forcing datasets can cause uncertainties when attributing global ET changes. (Vinukollu et al., 2011; Badgley et al., 2015; Miralles et al., 2016; Michel et al., 2016). For example, Miralles et al (2016) evaluated the performances of three models using the same forcing data, finding that the GLEAM product was relatively better than the other global ET products over most wet and dry conditions. Similarly, Badgley et al (2015) used 19 different combinations of input forcing datasets to run the Priestly-Taylor Jet Propulsion Laboratory (PT-JPL) ET model, indicating that the choice of forcing datasets accounted for $20 \%$ error range averagely. Those results have indicated that the improper choice of ET models and forcing data may add significant uncertainties into the ET attributions.

Potential ET (PET) is determined by radiation, air temperature, VPD, and wind speed, and it reflects the magnitude of atmospheric demand on land ET. In the warming climate, rising air temperature has increased atmospheric water demand (i.e. increased PET) (Fu et al., 2014; Feng et al., 2013; Dai et al., 2004). Studies have indicated that the recent PET increase is mostly determined by increased VPD which is a function of air temperature and humidity (Dai et al., 2017; Ficklin et al., 2017). Increased VPD tends to make plants close their stomata to avoid water loss, and thus restrain transpiration (Novick et al., 2016; McAdam et al., 2015). A high atmospheric water demand induced by VPD promotes PET, while the increasing surface resistance limits ET. Li et al. (2021) have found VPD has dominated the increase of annual ET in energy-limited regions such as southeastern China. It's not clear that how VPD affects global long term ET changes.

Furthermore, the above studies focused on the influences of climatic variables on long term ET changes, but there was a distinct shortcoming in the these studies, in which researchers only demonstrated the responses of long term ET change (variance) to some certain factors (e.g. climatic variables and surface conductance). And few studies can disentangle the contributions of relatively complete climatic factors, including precipitation, net radiation, air temperature, VPD, and wind speed, to annual ET linear trend. The limitation hinders the understanding of global ET changes, and ecosystem water and carbon fluxes.

In this study, we have adopted the Budyko theory to advance our understanding on the response of global ET trends to climatic variables, including precipitation $(\mathrm{P})$, net radiation $\left(\mathrm{R}_{\mathrm{n}}\right)$, air temperature $\left(\mathrm{T}_{1}\right)$, VPD, and wind speed $(\mathrm{u})$. The Budyko theory investigates the interactions between ET, PET, and P (Yokoo et al., 2008; Yang et al., 2008; Liu et al., 2011). For example, Teuling et al. (2019) explored the dynamics of ET in Europe at high resolution ( $\left.1 \mathrm{~km}^{2}\right)$ with Budyko model and key meteorological variables. Here we use multiple datasets such as GLEAM3.0a, EartH2Observe ensemble (EartH2ObserveEn), GLDAS2.0-Noah and MERRA-Land (Modern Era Retrospective-Analysis for Research and Application-Land). Using multiple datasets can reduce uncertainties of the forcing data so that we can accurately attribute global ET changes over different land covers and climate regimes (Michel et al., 2016; Dutra et al., 2015; Rodell et al., 2004; Reichle et al., 2011; Li et al., 2018).

\section{Data and Methods}




\subsection{Data}

We use various ET products and their respective forcing data, including the remote sensing-based GLEAM product, land surface model ensembled product (EartH2Oberve-En) and two reanalysis products (GLDAS2.0-Noah and MERRA-Land). These products have different temporal lengths, and we have used their overlapping period of 1980-2010. To study the ET mechanism within different climatic conditions, we have divided the global land into Tropical, Dry, Mild Temperate, Snow, and Polar zone respectively using the Köppen climate classification (Kottek et al., 2006) (Fig. 1).

\subsubsection{ET products}

a) GLEAM3.0a ET

The GLEAM3.0a is arguably the longest one of various ET products, which is determined mainly from remote sensing observations. It consists of soil evaporation, canopy transpiration, interception loss, snow sublimation, and open-water evaporation. A key feature of this product is where the Gash analytical model is used to estimate interception loss. The other components in this product are calculated according to Priestley-Taylor equation (Miralles et al., 2011b; Martens et al., 2017).

\section{b) EartH2Oberve-En ET}

The EartH2Oberve product uses ten models, including five hydrological models, four land surface models and a simple water balance model, which are forced by the same state-of-the-art-meteorological reanalysis (Dutra et al., 2015). Schellekens et al. (2017) indicated that the model ensemble outperforms individual model's output, and thus we have used the ensembled mean data from the ten models here (regarded as EartH2Oberve-En). The EartH2Oberve-En product is demonstrated to be an accurate reanalysis data and has been used for multiple-scale water resource evaluation (Schellekens et al., 2017).

\section{c) GLDAS2.0-Noah ET}

The GLDAS was initially developed by National Aeronautics and Space Administration (NASA) Goddard Space Flight Center (GSFC) of America, based on the North American Land Data Assimilation System (NLDAS). GLDAS is a global, high-resolution, offline terrestrial modeling system and produces the outputs of land surface states and fluxes in near-real time, such as ET, soil moisture, latent, sensible, and ground heat flux. Satellite and ground-based observations are used to constrain the forcing and parameterization of used land surface models (i.e. Mosaic, Noah, the Community Land Model, and the Variable Infiltration Capacity model) (Rodell et al., 2004). Here, the ET product derived from GLDAS2.0-Noah is used in our study.

\section{d) MERRA-Land ET}

The MERRA reanalysis was generated by Global Modeling and Assimilation Office (GMAO) in NASA. It was produced by the Goddard Earth Observing System model Version 5 (GEOS-5) along with its associated data assimilation system (DAS) Version 5.2.0 (Rienecker at al., 2011). Since there are significant errors in values and timing of precipitation in the original MERRA product (Reichle et al., 2011), we have used the offline MERRA-Land product forced by corrected precipitation. It is demonstrated that the hydrological performance in the MERRA-Land has been significantly improved than in the original MERRA product (Reichle et al., 2011). 


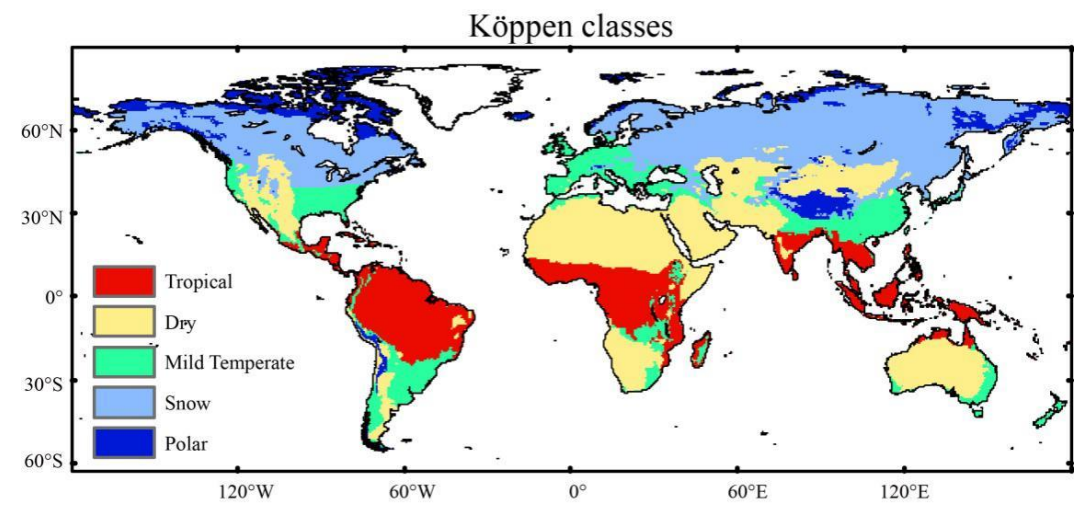

Figure 1. Spatial distribution of five climatic zones with Köppen climate classification, including Tropical, Dry, Mild Temperate, Snow, and Polar zone (Kottek et al., 2006).

\subsection{Forcing data}

5 The forcing data in four ET products mainly include precipitation, net radiation, air temperature, specific humidity, and wind speed. The forcing data of respective ET product and their references are listed in Table 1 ( $\mathrm{Li}$ et al., 2021). To reduce the uncertainties associated with inconsistent forcing data sources, the trends of each ET product are attributed using its own forcing data. Different from the other three products, the GLEAM algorithm does not use specific humidity and wind speed as inputs. Since the other forcing data of GLEAM product (e.g. radiation and air temperature) is derived from the ERAInterim reanalysis, specific humidity and wind speed from the same reanalysis is used for its attribution.

Table 1. The main forcing data in four ET products

\begin{tabular}{cccccccc}
\hline ET Products & Precipitation & Radiation & $\begin{array}{c}\text { Air } \\
\text { temperature }\end{array}$ & $\begin{array}{c}\text { Specific } \\
\text { humidity }\end{array}$ & Wind speed & References \\
\hline GLEAM3.0a & MSWEP & ERA-Interim & ERA-Interim & $\begin{array}{c}\text { ERA- } \\
\text { Interim }\end{array}$ & ERA-Interim & $\begin{array}{l}\text { Martens et al., } \\
2017\end{array}$ \\
EartH2Observe-En & WFDEI & WFDEI & WFDEI & WFDEI & WFDEI & $\begin{array}{l}\text { Schellekens et } \\
\text { al., 2017 }\end{array}$ \\
GLDAS2.0-Noah & PUMFD & PUMFD & PUMFD & PUMFD & PUMFD & $\begin{array}{l}\text { Rodell et al., } \\
2004\end{array}$ \\
MERRA-Land & CPC-U & MERRA & MERRA & MERRA & MERRA & $\begin{array}{l}\text { Reichl et al., } \\
2011\end{array}$ \\
\hline
\end{tabular}

Note: MSWEP indicates the Multi-Source Weighted-Ensemble Precipitation product; WFDEI is the Water and Global Change FP7 project forcing dataset ERA-Interim (Weedon et al., 2015; Dee et al., 2011); PUMFD indicates the meteorological forcing data of Princeton University (Sheffield et al., 2006); CPC-U is Climate Prediction Center Unified.

\subsection{Method}

\subsubsection{Determining trends}

We have used the Theil-Sen's slope method to determine the trends of annual ET and climatic variables during 1980-2010. This method is non-parametric, and can provide more accurate trend estimation for skewed data, when compared to the linear regression approach (Wilcox, 2010). To detect the significance level of these data, we used the non-parametric MannKendall test to determine the significance level of the linear trends (Mann, 1945 and Kendall, 1975). Both methods have been widely used in climate change studies (Su et al., 2015; Wang et al., 2018a; Shan et al., 2015; Shi et al., 2016).

\subsubsection{Attribution method}

The attribution method consists of two steps: firstly, building the relationship between ET and five climatic variables abovementioned with Budyko and modified FAO Penman-Monteith equations; secondly, conducting sensitivity experiment analysis to quantifying the contribution of each climatic variable to the long-term ET trends of 1980-2010. 
The Budyko equation (Equation 1) is usually regarded as a common way to study how climatic factors influence the annual ET changes, based on the mathematical relationships between precipitation, PET, and ET (Yokoo et al., 2008; Yang et al., 2009; Liu et al., 2011).

$$
\frac{E T}{P}=1+\frac{P E T}{P}-\left[1+\left(\frac{P E T}{P}\right) \underline{\omega}\right]^{\frac{1}{\omega}}(1)
$$

where ET, PET, and P reflect ET, potential ET, and precipitation, respectively; $\underline{\omega}$ indicates the landscape property, such as vegetation cover, soil properties and topography. For a certain product, pixel-wise $\underline{\omega}$ can be fitted by using the least-squared regression method because other variables during 1980-2010 are known (i.e. ET, P, and PET). PET reflects the atmospheric water demand, which can be determined by solar radiation, air temperature, actual vapor pressure, and wind speed etc.

There are various methods for calculating PET, including Penman-Monteith (Allen et al., 1998), Hargreaves (Hargreaves and Samani, 1985), and Priestly-Taylor methods (Priestley and Taylor, 1972). Generally, the modified FAO Penman-Monteith equation is a universal method for estimating PET with meteorological data (Allen et al., 1998). In the study, annual PET is obtained with the modified Penman-Monteith equation:

$$
P E T=\frac{0.408 \Delta\left(R_{n}-G\right)+\gamma \frac{900}{T 1+273} u V P D}{\Delta+\gamma(1+0.34 u)}
$$

where $R_{n}$ represents net radiation, calculated by net incoming shortwave minus net outgoing longwave radiation (unit: $\mathrm{MJ} / \mathrm{m}^{2} / \mathrm{yr}$ ); G is the soil heat flux density (unit: $\mathrm{MJ} / \mathrm{m}^{2} / \mathrm{yr}$ ), and can be neglected on monthly or longer time scales; $\gamma$ and $\Delta$ reflect the psychometric constant and slope of vapor pressure curve, respectively (unit: $\mathrm{kPa} /{ }^{\circ} \mathrm{C}$ ); $\mathrm{T}_{1}$ indicates mean temperature in the 2-meter air (unit: ${ }^{\circ} \mathrm{C}$ ), and is used to calculate $\Delta ; u$ indicates 2-meter wind speed (unit: $\left.\mathrm{m} / \mathrm{s}\right) ; \mathrm{VPD}(\mathrm{kPa})$ is the saturation vapour pressure deficit, as a function of air temperature $T_{2}$ and specific humidity (i.e. $V P D=f\left(T_{2}\right.$, specific humidity)). In Eq(2), the effect of air temperature $T$ on PET is separated into two parts: $T_{1}$ and $T_{2} . T_{1}$ reflects the effect of air density and slope of vapor pressure curve, and $\mathrm{T}_{2}$ indicates the part effect of VPD. The more details of the calculation of VPD and difference between $T_{1}$ and $T_{2}$ can refer to Allen et al. (1998).

By putting $\mathrm{Eq}(2)$ into $\mathrm{Eq}(1)$, we can obtain the direct relationship between $\mathrm{ET}$ and $\mathrm{P}, \mathrm{R}_{\mathrm{n}}, \mathrm{T}_{1}, \mathrm{VPD}$ and $u$ :

$$
E T=P+\frac{0.408 \Delta\left(R_{n}-G\right)+\gamma \frac{900}{T 1+273} u V P D}{\Delta+\gamma(1+0.34 u)}-P\left[1+\left(\frac{0.408 \Delta\left(R_{n}-G\right)+\gamma \frac{900}{T 1+273} u V P D}{P(\Delta+\gamma(1+0.34 u))}\right) \underline{\omega}\right]^{\frac{1}{\omega}}
$$

b) Attribution experiments

The trends of annual ET during 1980-2010 are determined by compound influences of the main climatic factors (i.e. P, $R_{n}$, $\mathrm{T}_{1}$, VPD, and $u$ ). To disentangle the impact of each climatic factor, six experiments have been designed based on Eq (3), including one control experiment (sim_CTL) and five individual factor's sensitivity experiments (sim_P, sim_ $R_{n}, \operatorname{sim}_{-} T_{1}$, sim_VPD, and sim_ $u$ respectively). The sim_CTL experiment can obtain the control ET changes for each product by using all the factors of 1980-2010, while the ET change controlled by one certain factor is simulated by the sensitivity experiment with the factor only in the 1980 and the others factors of 1980-2010. For example, the ET change of 1980-2010 impacted by $\mathrm{P}$ (i.e. sim_P) can be computed by using constant value of $\mathrm{P}$ in 1980, as well as $\mathrm{R}_{\mathrm{n}}, \mathrm{T}_{1}$, VPD, and $u$ of 1980-2010. The contributions of the other climatic factors $\left(\operatorname{sim}{ }_{-} \mathrm{R}_{\mathrm{n}}, \operatorname{sim}_{-} \mathrm{T}_{1}, \operatorname{sim} \_\mathrm{VPD}\right.$, and sim $\_u$ ) can be determined similarly for each product. The contribution of each factor to ET change in each product is obtained (Sun et al., 2016 and 2017):

$$
C_{i}=\frac{\sum_{k \neq i}^{n} E_{\text {Sim } \_k}-(n-2) \cdot E_{\text {Sim } \_i}}{n-1} .
$$

where $n$ shows the number of sensitivity experiments, and $\mathrm{n}$ is equal to 5 here; and $\mathrm{E}_{\text {sim_i }}$ indicates the $i^{\text {th }}$ sensitivity experiment. We should note that the total contribution of air temperature $T$ to ET changes here is separated into two sensitivity experiments: $\operatorname{sim}{ }_{-} T_{1}$ and sim_VPD. The sim_ $T_{1}$ means the effect of air temperature $T_{1}$ in Eq (2) on ET; the 
sim_VPD, controlled by air temperature $\mathrm{T}_{2}$ and specific humidity, contains the contribution of air temperature $\mathrm{T}_{2}$.

\section{Results}

\subsection{Trends of the ET products}

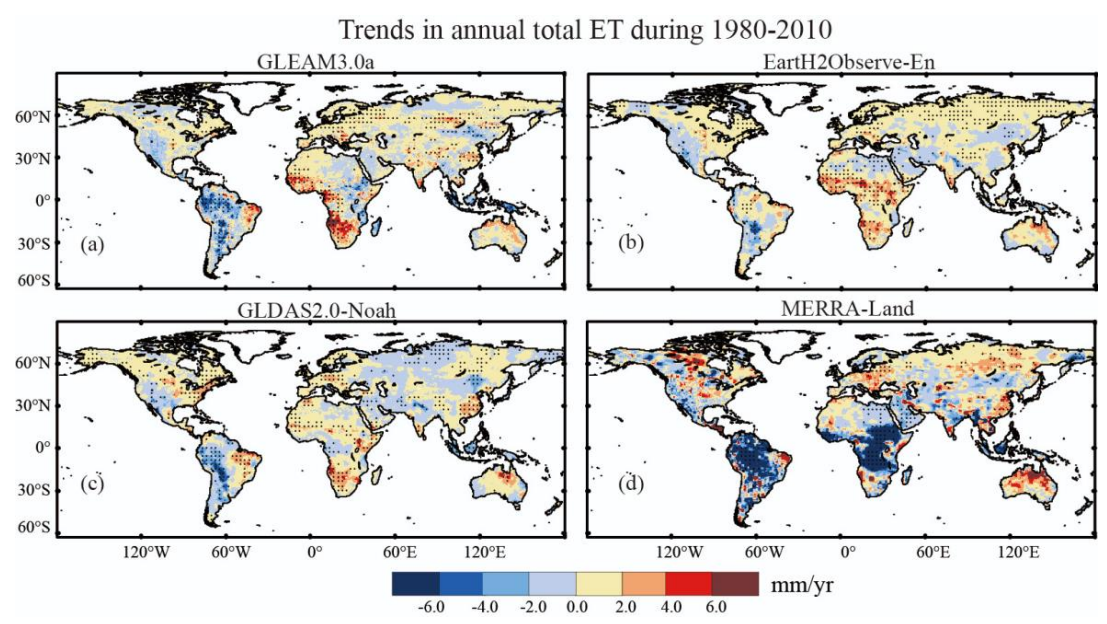

5 Figure 2. The spatial distribution of pixel-wise linear trends of annual ET for (a) GLEAM3.0a, (b) EartH2Observe-En, (c) GLDAS2.0-Noah and (d) MERRA-Land products during 1980-2010. The trend is estimated with the Theil-Sen's slope method and the significance level is tested with the Mann-Kendall method. Dotted area indicates the trend has passed significance test at $5 \%$ level.

The spatial distribution of long-term trends in annual ET is depicted in Fig. 2, with evident differences and similarities among the selected four products in different regions. Compared to the other products, the MERRA-Land shows more significant ET changes, for example, the declining trend with a rate of about $-6.0 \mathrm{~mm} / \mathrm{yr}$ in Africa and South America. In most regions of Eurasia continent, the ET changes for all products mainly amounts to $-2.0-2.0 \mathrm{~mm} / \mathrm{yr}$. Significantly increasing ET is observed in the west Europe, southeast China and north Australia, while declining ET is observed in northeast China and Arabian Peninsula, despite differences existing among the used ET products. These products show quite different trends in Africa; while the MERRA-Land indicates significantly declining ET, the trends in the other products are obviously opposite.

\subsection{Attributions of ET trends}

The influence of each driving factor on long-term annual ET linear trend is quantified by the attribution method in Sect. 2.2.2. Figure 3 shows the trends in each variable and its respective contribution to ET changes across different climate zones. Precipitation $(\mathrm{P})$ appears to make the largest contribution, air temperature $\left(\mathrm{T}_{1}\right)$ and wind speed $(u)$ make the smallest (except $u$ in MERRA-Land), and contributions of net radiation $\left(\mathrm{R}_{\mathrm{n}}\right)$ and VPD are in between.

Compared to other products, more sharply decreasing $u$ in MERRA-Land leads to a negative ET trend. The grid number of $\mathrm{P}$ in the first and third quadrants is more than $85 \%$ of the sum in Fig. 3a, indicating P is positively correlated with ET. ET in Dry zone is more sensitive to changes in $\mathrm{P}$, while it is insensitive in Tropical zone. Such a relationship also exists in $\mathrm{R}_{\mathrm{n}}$ (Fig. 3b), VPD (Fig. 3d), and $u$ (Fig. 3e). Different contributions among climatic zones are also observed for $\mathrm{R}_{\mathrm{n}}$ (Fig. 3b) and VPD (Fig. 3d). For example, the $R_{n}$ contribution in Tropical zone exceeds that in Mild Temperate zone, while the VPD contribution in Mild Temperate zone is large than that in Tropical zone. Limited grids, mostly from water-limited region (Dry), fall in the fourth quadrant, amounting to $25.26 \%-41.96 \%$ of the sum, suggesting increasing $\mathrm{T}_{1}$ hinders ET. 

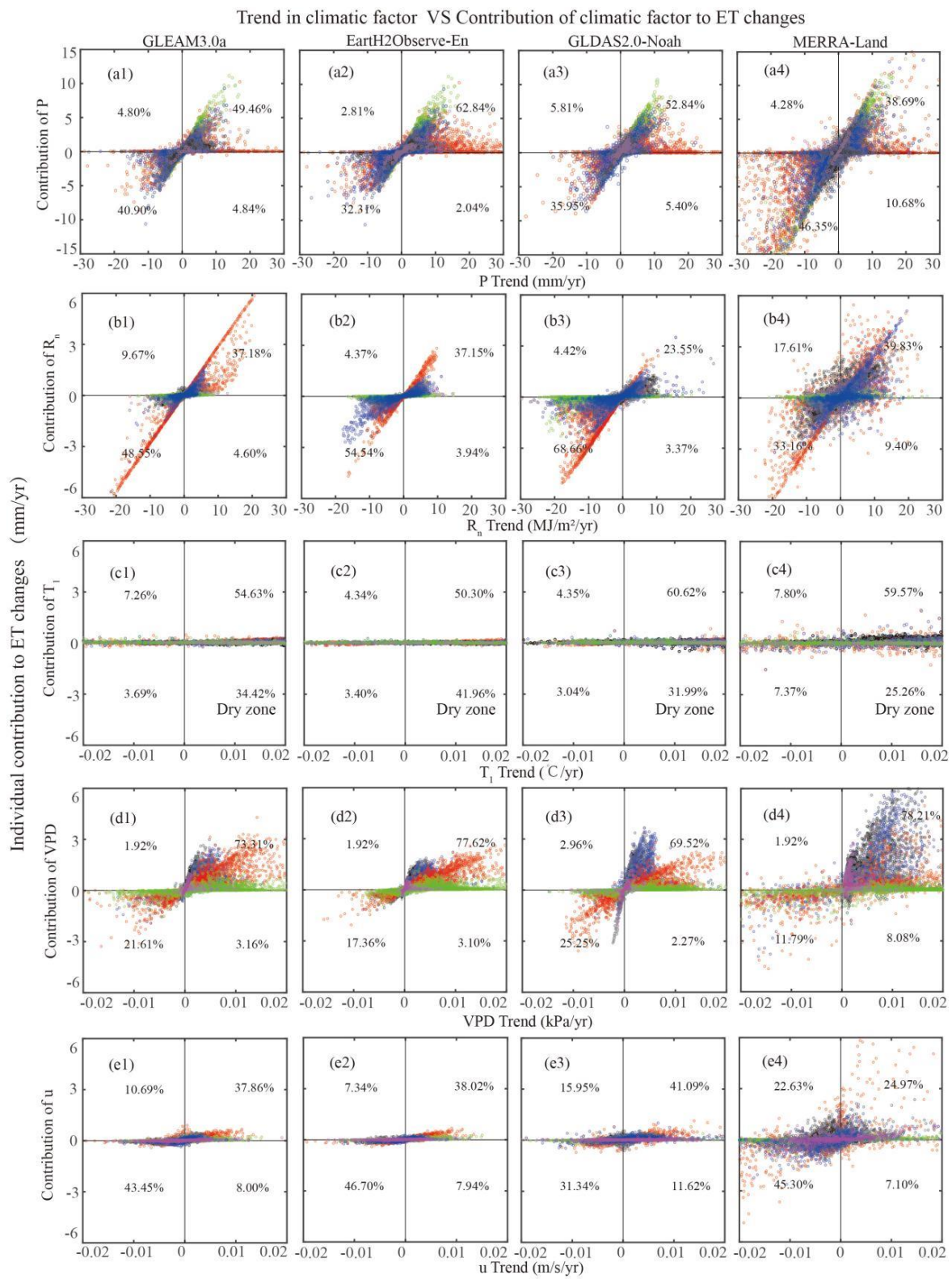

O Tropical $\bigcirc$ Dry O Mild Temperate O Snow O Polar

Figure 3. Pixel-wise scatterplots of ( $x$-axis) trends in each climatic variable against (y-axis) the contribution of each climatic variable to ET changes. Small letters (a-e) indicate precipitation, radiation, air temperature $\left(\mathrm{T}_{1}\right)$, VPD and wind speed, respectively; and numbers (1-4) indicate GLEAM3.0a, EartH2Observe-En, GLDAS2.0-Noah and MERRA-Land respectively. The percentage is the ratio between the number of grid cells in each quadrant and the number of total grid cells; the sum of the percentage values in four quadrants equals to $100 \%$. The color red, green, blue, black purple represents Tropical, Dry, Mild Temperate, Snow, Polar zones, respectively. 

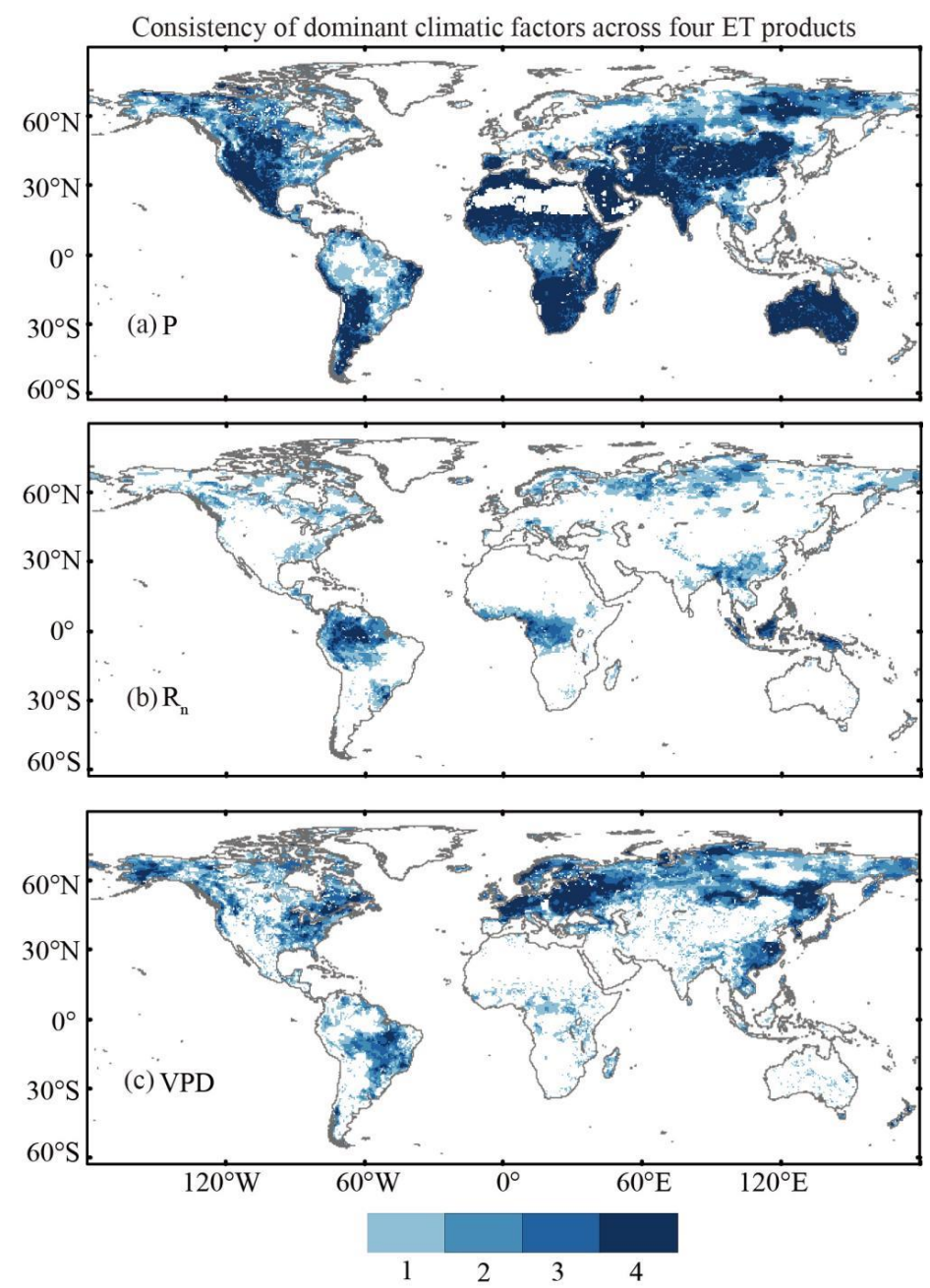

Figure 4. The consistency of spatial distribution of dominant climatic factors to global long-term ET trends between GLEAM3.0a, EartH2Observe-En, GLDAS2.0-Noah and MERRA-Land for Precipitation (a), net radiation (b), and VPD (c). The land fraction of air temperature $\left(T_{1}\right)$ and wind speed is limited, and the results of the two factors are not showed here. 5 Number 1-4 represent the count of these models with the same dominant factor in one pixel, and indicate different confidence level from low to high.

To further show the spatial distribution of these driving factors affecting ET, we compare the consistency of dominant climatic factors across these ET products in Fig. 4. The results indicate that precipitation is the dominant factor of ET trends in the entire Dry zone and some regions of the others climate zones in all models, such as northeast and south part of Snow zone, Mild Temperate zone in South America; net radiation dominates the ET trends in most of Tropical zone; and VPD dominates the ET trends in the entire Mild Temperate zone, Eastern Europe and Northeast Asia in Snow zone. In Table 2, we can see that precipitation, net radiation, and VPD are the dominant factors of ET changes in most global land. For example, precipitation makes dominant contribution to ET trends, either positive or negative, in 55.41 percentages of the global grids.

Table 2. The percentage of grids in each dominant factor controlling annual ET linear trends for GLEAM3.0a, respectively.

\begin{tabular}{ccccccc}
\hline & & $\mathrm{P}$ & $\mathrm{R}_{\mathrm{n}}$ & $\mathrm{T}_{1}$ & $\mathrm{VPD}$ & $\mathrm{u}$ \\
\hline GLEAM3.0a & + & $30.34 \%$ & $4.03 \%$ & $0.79 \%$ & $27.32 \%$ & $0.06 \%$ \\
& - & $25.07 \%$ & $7.27 \%$ & $0.08 \%$ & $4.87 \%$ & $0.18 \%$ \\
\hline
\end{tabular}




\begin{tabular}{ccccccc}
\hline EartH2Observe-En & + & $42.70 \%$ & $4.65 \%$ & $0.44 \%$ & $24.88 \%$ & $0.06 \%$ \\
& - & $19.94 \%$ & $4.90 \%$ & $0.02 \%$ & $2.30 \%$ & $0.10 \%$ \\
GLDAS2.0-Noah & + & $31.27 \%$ & $4.17 \%$ & $0.93 \%$ & $20.88 \%$ & $0.10 \%$ \\
& - & $23.67 \%$ & $13.73 \%$ & $0.01 \%$ & $5.17 \%$ & $0.07 \%$ \\
\multirow{2}{*}{ MERRA-Land } & + & $26.77 \%$ & $5.60 \%$ & $0.08 \%$ & $29.09 \%$ & $0.06 \%$ \\
& - & $30.43 \%$ & $6.46 \%$ & $0.22 \%$ & $0.87 \%$ & $0.42 \%$ \\
\hline
\end{tabular}

3.3 Validations of attribution method
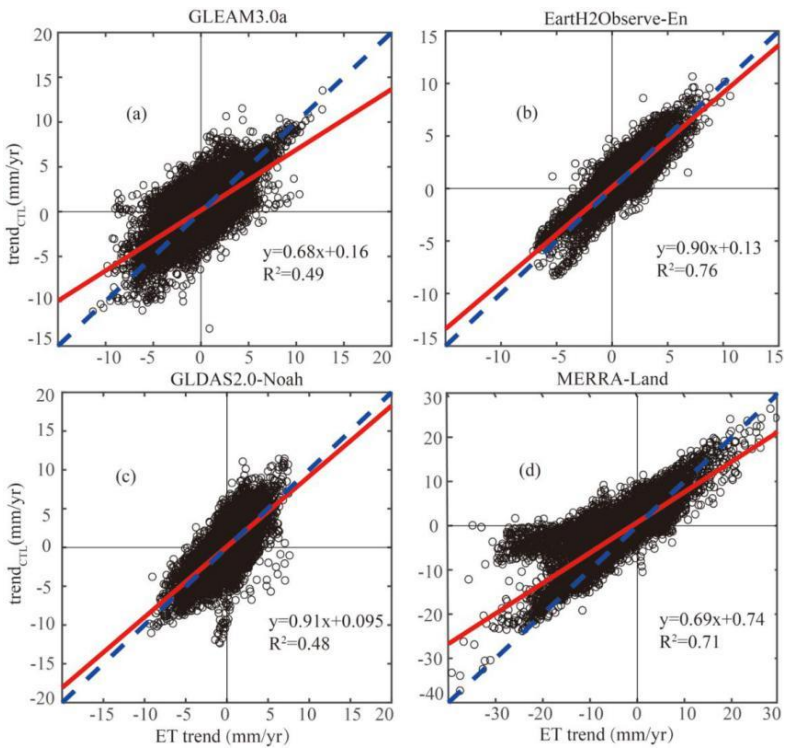

Figure 5. The pixel-wise scatterplots of global long-term annual ET linear trend against the control trend (trend $\mathrm{CTL}_{\mathrm{CT}}$ ) in ET for GLEAM3.0a (a), EartH2Observe-En (b), GLDAS2.0-Noah (c), and MERRA-Land (d). The red line indicates a fitted line of the scatter points along with the 1:1 blue dotted line.

A separation method in this study is used to obtain the respective contribution of each driving factor to long-term annual ET linear trend, which inevitably is suspected to produce some uncertainties in the attribution results. Figure 5 shows the scatter plots of the pixel-wise ET trend in the four products against those from the CTL experiment, in order to validate the accuracy of reproducing ET with the fitted relations using Equation 3 and the five selected climatic variables. The resultant $\mathrm{R}^{2}$ values range from 0.48 to 0.76 , indicating that the trend $\mathrm{C}_{\mathrm{CTL}}$ simulated by Equation 3 can principally reproduce the ET trends as in the four products. Meanwhile, scatter plots of the accumulative contributions of the driving factors $\left(\sum_{i=1}^{5} C_{i}\right)$ in each product against the respectively simulated trend $\mathrm{CTL}_{\mathrm{CT}}$ are shown in Fig. 6, in order to understand the possible uncertainties of such an analysis. Strikingly, the $\mathrm{R}^{2}$ values are all higher than 0.99 , indicating that the summed contributions of the driving factors are almost equals to the realistic global ET trends in all products. 

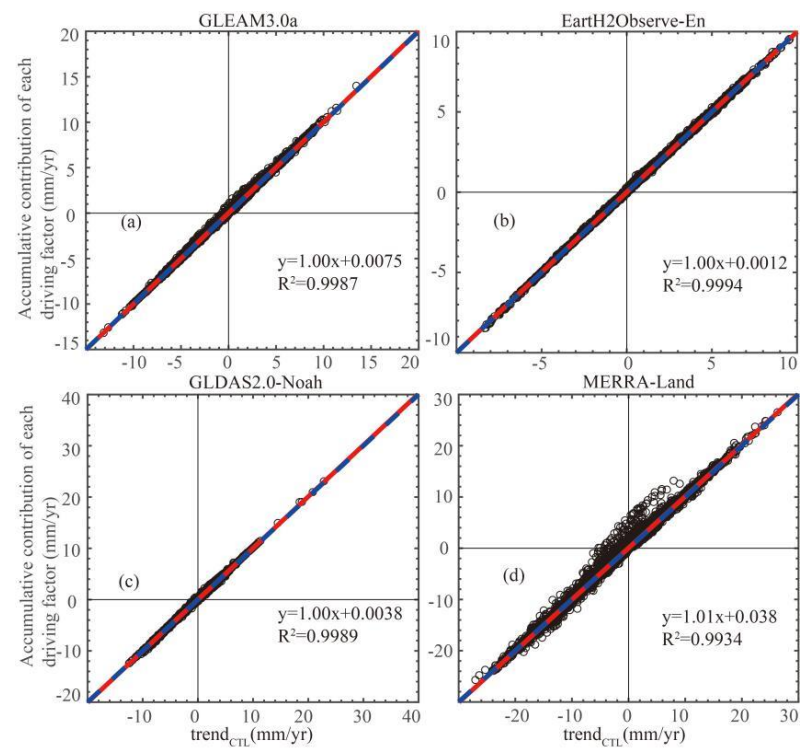

Figure 6. The pixel-wise scatterplots of the accumulative contributions of five selected driving factors against the control trend (trend $\mathrm{CTL}_{\mathrm{CT}}$ ) in ET for GLEAM3.0a (a), EartH2Observe-En (b), GLDAS2.0-Noah (c), and MERRA-Land (d). The red line indicates a fitted line of the scatter points along with the $1: 1$ blue dotted line.

5

\subsection{Results comparison}

In this study, we have found the global ET trends during 1980-2010 in GLEAM3.0a, EartH2Oberve-En, GLDAS2.0-Noah, and MERRA-Land products are relatively consistent. A significantly increasing ET pattern is found in some regions of the west Europe and southern Asia, north-middle region of Australia, while a declining ET pattern is observed in the west North

America and South America. Similar global ET patterns are also found in Pan et al. (2020) based on multi-source products. However, different ET trends are observed among these products in Africa and South America, where the MERRA-Land shows a significant decrease of about $-5.0 \mathrm{~mm} / \mathrm{yr}$.

How climatic variable controls the global ET trend is one of the important questions we ask in this study. So that we have designed sensitivity experiments to disentangle contributions from each climatic driver (precipitation, net radiation, air temperature, VPD, and wind speed). Precipitation, net radiation, VPD, and wind speed contribute the most to the changes in global ET with an inferred positive relationship, while an increase in temperature shows the opposite in some regions. The positive relationships between ET and precipitation, net radiation have been confirmed by Lu et al. (2019), Wang et al. (2018b), Pan et al. (2020), and Soni et al. (2021). Precipitation supplies water, and net radiation provides energy for the ET process, respectively. However, the increased temperature appears to have influenced the mechanism of ET trend differently between the water-limited region (dry zone) and other regions. Rising air temperature can lead to soil moisture depletion followed by suppressed vegetation growth in the water-limited regions (Jung et al., 2010; Zhang et al., 2019).

Meanwhile, we found that an increased VPD tends to promote atmospheric processes followed by global ET changes. Even if increased VPD reduces surface conductance, increased atmospheric water demand by VPD absorbs moisture from soil and vegetation, thus increasing ET (Grossiord et al., 2020). The positive feedbacks are also verified by Hogg and Hurdle, (1997); Admiral et al. (2006); Sottocornola and Kiely, (2010); Kochendorfer et al. (2011); Wang et al. (2012); Yang et al. (2019). However, Novick et al (2016) indicated increased VPD due to warming increased surface resistance, limiting ET over many biomes. Massmann et al. (2019) suggested that ET response to increased VPD varied from decreasing to increasing, 
depending on plant water regulation strategies determined by climatic environment and plant types. For example, when compared to boreal and arctic climates, VPD increased ET in tropical and temperate climate; in terms of plant type, shrubs and gymnosperm trees decreased ET, while crops tended to increase ET. Therefore, we consider that the contrasting influence of VPD on ET should be addressed separately, emphasizing how the VPD affects the individual components of ET, which are evaporation from soil, and canopy interception and transpiration. To do this, more complex physical ET process combined with soil and plant resistance models should be used. For example, Grossiord et al. (2020) admitted that an increased VPD would make stomatal closure, but transpiration would still increase under a certain threshold across plants in different climate regions. Besides, they found the positive response of surface resistance to VPD increased from wetting to drying climate.

Most studies used the effect of VPD on ET as a surrogate of high air temperature as VPD is determined by air temperature and specific humidity. Relative to rapid air warming, change in the specific humidity are weak, resulting in increased VPD controlled by the rising air temperature. Figure 7 shows the spatial pattern of the climatic variables (i.e. air temperature $\mathrm{T}_{2}$ and specific humidity) that dominates the global VPD changes following our proposed sensitivity method. Our study concludes that the specific humidity controls VPD only in some regions of North and South Asia, northern Australia, southern Africa, and South America. However, vegetation physiology controlled by VPD plays important role in reshaping the hydrological cycle and global water resources compared to air temperature (Grossiord et al., 2020). Meanwhile, considering a close relationship between T and VPD, we attempted to separate the contribution to ET between VPD and air

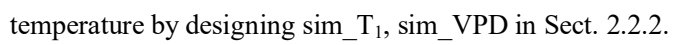

Dominant factors in VPD changes during 1980-2010
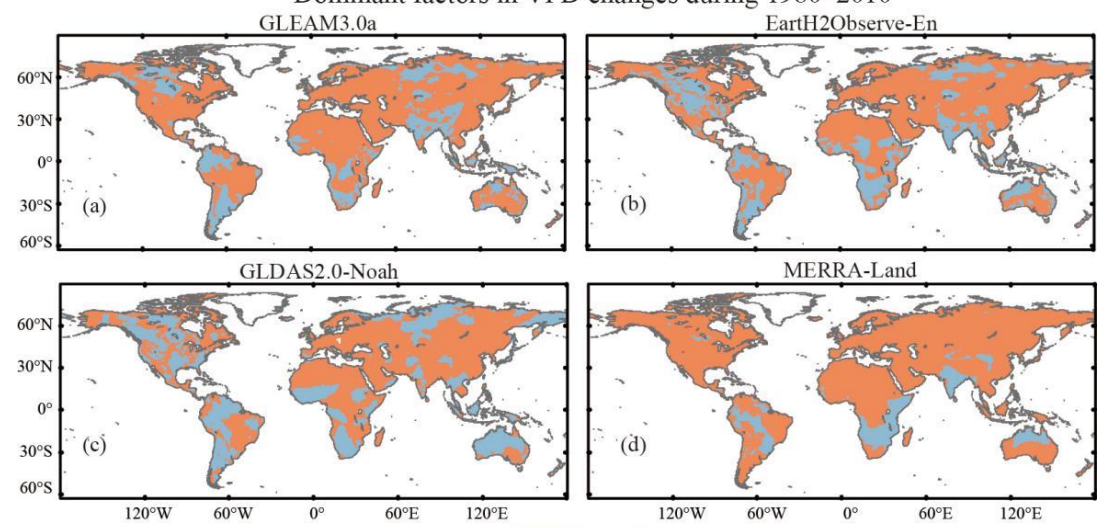

$\mathrm{T}_{2} \mathrm{H}$

Figure 7. Distribution of dominant factor in VPD changes in global land during 1980-2010 for GLEAM3.0a (a), EartH2Observe-En (b), GLDAS2.0-Noah (c), and MERRA-Land (d). $\mathrm{T}_{2}$ and $\mathrm{H}$ mean air temperature and specific humidity respectively.

Figure 4 shows the spatial distribution of climatic drivers controlling ET implying that precipitation is the primary driver that controls ET in Dry zone. This includes northern and southeastern Eurasia, most of Africa, the middle-west of North America, southern parts of South America, and almost entire Australia, while net radiation dominates the tropical zone. Why these two climatic drivers are important for controlling ET changes has also attracted the interest among other scientists (Pan et al., (2020) and Zhang et al., (2015)). Interestingly, we find that the impact of VPD on ET is mostly emphasized in some high latitude regions of the northern hemisphere, such as eastern North America, Europe, and northeastern Asia. Long-term ET changes in these regions are reported to be controlled by air temperature (Pan et al., (2020); Zhang et al., (2015)). However, in our study, the increased VPD caused by rising air temperature plays a significant role in controlling ET changes (Admiral et al., 2006; Sottocornola and Kiely, 2010; Kochendorfer et al., 2011; Yang et al., 2019). Actually, ET in high latitude region 
is controlled by VPD, rather than air temperature. Precipitation controls ET in water-deficit regions (Dry zone) by replenishing the storage deficit, and ET in the tropical rain forest (i.e. energy-limited region) is determined by available energy (i.e. net radiation).

\subsection{Uncertainties}

Budyko framework is the key component of the attribution method used in our study. Based on this hypothesis, Fu (1981) and Zhang et al. (2004) offered the best analytical solution (i.e. Sect. 2.2.1 equation (1)) through a dimensional mathematical analysis by providing the mathematical reasons. The key part of the analytical solution is that ET is determined by the ratio between PET and precipitation. The equation has been applied in numerous hydrological studies at the catchment scale. When using the hypothesis at the catchment scale, some details of the results related to the land features are often missing or ignored. However, when testing the same hypothesis at grid scales, the Budyko framework performance is outstanding (Greve et al., 2014; Teuling et al., 2019; Roderick et al., 2014). We have also validated the accuracy of the Budyko hypothesis by comparing the ET values estimated by the Budyko with actual ET values in Fig. 8 . The results with high $\mathrm{R}^{2}$ values for all products indicate the Budyko can be successfully applied in the attribution method. However, there are discrepancies among different PET calculation methods that may introduce some uncertainties into the attribution results.

For example, Zhou et al. (2020) have compared four temperature-based models (Hamon, Hargreaves-Samani, Oudin, Thornthwaite), two radiation-based models (Energy-Only and Priestley-Taylor), and two synthesis models (Penman and Penman-Monteith) of PET calculation in China as an example, and pointed out that the Penman-Monteith and Penman methods are almost similar, but better than the other remaining methods. Based on the results, Penman-Monteith method outperforms the Penman method, thus used to calculate the standard values of PET in our study.
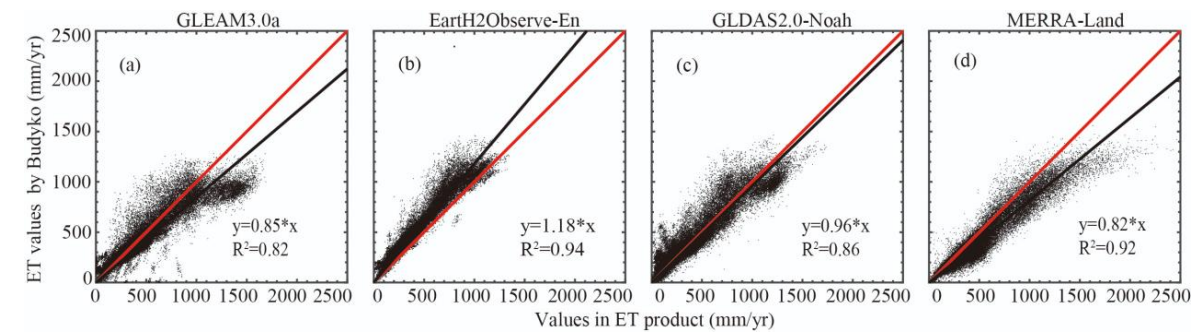

Figure 8. Pixel-wise scatterplots of (x-axis) annual ET in each product against (y-axis) annual ET estimated by Budyko Framework. Small letters (a-d) represent GLEAM3.0a, EartH2Observe-En, GLDAS2.0-Noah, and MERRA-Land, respectively.

The fitted parameter $\underline{\omega}$ in Equ (3) includes landscape characteristics, such as vegetation cover, soil properties, and topography (Xu et al., 2013). The parameter contains each model's characteristic, leading to uncertainties of the attribution method from forcing data and information in each product. The information consists of structure parameters of each model, and surface factors (land cover types, soil properties, and topography). The selected four products in the study use static surface factors when simulating ET. Given the reason, the attribution method has the limitation of not considering the influences of land surface on ET changes and only focuses on quantifying several climatic variables' influences here. In Sect. 3.3, we have evaluated the respective performance of this attributed method, suggesting these five climatic factors can represent ET changes.

Except climatic variables, we also admit that vegetation variability, soil moisture, and even $\mathrm{CO}_{2}$ concentration can influence long-term ET changes (Zhang et al., 2015; Jung et al., 2010; Suzuki et al., 2007; Wang et al., 2010; Yang et al., 2019). For example, vegetation changes influence the inter-annual changes of ET in growing seasons and affect spatio-temporal patterns and trends in ET from regional to global scale. Jung et al. (2010) found that drying soil in the Southern Hemisphere, particularly in Africa and Australia, was responsible for a decline in ET during 1998-2008. Elevated $\mathrm{CO}_{2}$ concentration can 
result in ET decrease by reducing the transpiration rate caused by the partial closure of the stomata in those regions where climate projections indicate excessive water-supply (Yang et al., 2019). For future studies, the contribution of land surface such as soil moisture, vegetation photosynthesis on ET should be investigated to better understand the mechanism of global ET trend.

\section{Conclusions}

We have estimated the linear ET trend globally during 1980-2010 from GLEAM3.0a, EartH2Oberve-En, GLDAS2.0-Noah, and MERRA-Land. Secondly, we obtained the respective contribution of each factor to ET trends with multiple sensitivity experiments and a separation method, and identified which factor controls global ET changes across different climate zones. The major findings are summarized below:

(1) ET changes: Long-term trend in ET during 1980-2010 is evident globally, especially in Africa and South America. Significantly increase in ET is observed in Eurasia, northern and central Australia, northeast Africa, eastern parts of South America and eastern parts of central North America. Decreasing ET is found in the west of North and South America, northeast of Africa, and the Arabian Peninsula. MERRA-Land has more significant ET changes when compared to the other products.

(2) Dominant factors: Precipitation, net radiation, VPD, and wind speed are positively correlated to global ET changes, while air temperature $\left(T_{1}\right)$ has contrast influences on ET between dry zone and other regions. Precipitation controls ET changes in Dry zone, including north, and central and southeast regions of Eurasia, most of Africa, central parts of western North America, southern parts of South America, and almost entire Australia, net radiation dominates the tropical zone. VPD dominates ET in some high latitude regions of the northern hemisphere, such as eastern North America, whole Europe, and northeastern Asia.

Data availability. In this study, each ET global product and respective forcing climatic factors can be d-ownloaded : GLEA M3.0a from https://www.gleam.eu/, EartH2Observe-En from http://www.earth2observe.eu/., GLDAS2.0-Noah from https://d isc.gsfc.nasa.gov/datasets?keywords=GLDAS, and MERRA-Land from https://disc.gsfc.nasa.gov/datasets?keywords=merraland\&page $=1$.

Author Contributions. Shijie Li, Guojie Wang, Jian Peng: Conceptualization, Methodology. Shijie Li, Guojie Wang, Chenxia Zhu: Data curation, Writing- Original draft preparation. Jiao Lu, Waheed Ullah, Daniel Fiifi Tawia Hagan, Giri Kattel: Writing-Reviewing and Editing. Guojie Wang, Jian Peng: Supervision.

Competing Interest. The authors declare that they have no known competing financial interests or personal relationships that could have appeared to influence the work reported in this paper.

Acknowledgments. This research was funded by National Key Research and Development Program o-f China (\#2017YFA0 603701), the National Natural Science Foundation of China (\#41875094), the Sin-o-German Cooperation Group Project (\#G Z1447), and Postgraduate Research and Practice Innovation Program of Jiangsu Province (\#KYCX20_0932).

\section{References}

Admiral, S. W., P. M. Lafleur, and N. T. Roulet.: Controls on latent heat flux and energy partitioning at a peat bog in eastern

Ahmadi, B., Ahmadalipour, A., Tootle, G., \& Moradkhani, H.: Remote Sensing of Water Use Efficiency and Terrestrial Drought Recovery across the Contiguous United States. Remote Sensing, 11(6), 731, 10.3390/rs11060731, 2019.

Allen, M. R. \& Ingram,W. J.: Constraints on future changes in climate and the hydrologic cycle. Nature, 419, 224-232, 
10.1038/nature01092, 2002.

Allen, R.G., Howell, T.A., Pruitt, W.O., Walter, I.A., Jensen, M.E.: Lysimeters for Evapotranspiration and Environmental Measurements, American Society of Civil Engineers: New York, NY, USA, p. 456, 1991.

Allen, R.G., Pereira, L.S., Raes, D., Smith, M.: Crop Evapotranspiration: Guidelines for Computing Crop Requirements,

Badgley, G., Fisher, J.B., Jiménez, C., Tu, K.P.,Vinukollu, R.: On Uncertainty in Global Terrestrial Evapotranspiration Estimates from Choice of Input Forcing Datasets. J. Hydrometeorol., 16, 1449-1455, 10.1175/JHM-D-14-0040.1, 2015.

Budyko, M.: Climate and Life (508pp). Academic Press, New York, 1974.

Dai, A., Trenberth, K.E., Qian, T.: A global dataset of Palmer Drought Severity Index for 1870-2002: relationship with soil moisture and effects of surface warming. J. Hydrometeorol., 5, 1117-30, 10.1175/JHM-386.1, 2004.

Dai A, Zhao T.: Uncertainties in historical changes and future projections of drought. Part I: estimates of historical drought changes. Climatic Change, 144:519-33, 10.1007/s10584-016-1705-2, 2017.

Dee, D.P., Uppala, S.M., Simmons, A.J., Berrisford, P., Poli, P., Kobayashi, S., Andrae, U., Balmaseda, M.A., Balsamo, G., Bauer, P., et al.: The ERA-Interim reanalysis: Configuration and performance of the data assimilation system. Q. J. R. Meteorol. Soc. 137, 553-597, 10.1002/qj.828, 2011.

Douville, H., Ribes, A., Decharme, B., Alkama, R., and Sheffield, J.: Anthropogenic influence on multidecadal changes in reconstructed global evapotranspiration, Nat. Clim. Change, 3, 59-62, 10.1038/nclimate1632, 2013.

Dutra, E., Balsamo, G., Calvet, J. C., Minvielle, M., Eisner, S., Fink, G., Pessenteiner, S., Orth, R., Burke, S., van Dijk, A.I.J.M., et al.: Report on the current state-of-the-art Water Resources Reanalysis. Available online: http://earth2observe.eu/files/PublicDeliverables /D5.1_ReportontheWRR1tier1.pdf (accessed on31 March 2015).

Everson, C.S., Clulow, A., Mengitsu, M.: Feasibility Study on the Determination of Riparian Evaporation in Non-Perennial Systems; WRC Report No. TT 424/09, Water Research Commission: Pretoria, South Africa, 2009.

Feng S, Fu Q.: Expansion of global dry lands under warming climate. Atmos. Chem. Phys., 13, 10081-10094, 10.5194/acp13-10081-2013, 2013.

Ficklin, D.L., Novick, K., A.: Historic and projected changes in vapor pressure deficit suggest a continental-scale drying of the United States atmosphere. J. Geophys. Res. Atmos., 122, 2061-79, 10.1002/2016JD025855, 2017.

Fu Q, Feng S.: Responses of terrestrial aridity to global warming. J. Geophys. Res. Atmos., 119, 7863-75, 10.1002/2015JD024100, 2014.

Fu, B.: On the calculation of the evaporation from land surface. Sci. Atmos. Sin., 5:23-31, 1981. [in Chinese].

Greve, P., Orlowsky, B., Mueller, B., Sheffield, J., Reichstein, M., and Seneviratne, S. I.: Global Assessment of Trends in Wetting and Drying over Land, Nat. Geosci., 7, 716-721, 10.1038/ngeo2247, 2014.

Grossiord, C., Buckley, T. N., Cernusak, L. A., Novick, K. A., Poulter, B., Siegwolf, R. T. W., ... McDowell, N. G.: Plant responses to rising vapor pressure deficit. New Phytologist, 226, 1550-1566, 10.1111/nph.16485, 2020.

Haddeland, I., Clark, D.B., Franssen, W., Ludwig, F., Voß, F., Arnell, N.W., Bertrand, N., Best, M., Folwell, S.,Gerten, D., et al.: Multi model estimate of the global terrestrial water balance: Setup and first results. J. Hydrometeorol., 12, 869-884, 10.1175/2011JHM1324.1, 2011.

Hargreaves, G.H., Samani, Z.A.: Reference crop evapotranspiration from temperature. Appl. Eng. Agric. 1, 96-99, 10.13031/2013.26773, 1985.

Hogg, E. H., and Hurdle, P. A. Sap flow in trembling aspen: Implications for stomatal responses to vapor pressure deficit, Tree Physiol.17(8-9), 501-509, 10.1093/treephys/17.8-9.501, 1997.

Jalilvand, E., Tajrishy, M., Ghazi Zadeh Hashemi, S. A., \& Brocca, L.: Quantification of irrigation water using remote sensing of soil moisture in a semi-arid region. Remote Sensing of Environment, 231, 111226, 10.1016/j.rse.2019.111226, 2019. 
Jung, M., Reichstein, M., Bondeau, A.: Towards global empirical upscaling of FLUXNET eddy covariance observations: Validation of a model tree ensemble approach using a biosphere model. Biogeosciences, 6, 2001-2013, 10.5194/bgd-6-52712009, 2009.

Jung, M., Reichstein, M., Ciais, P., Seneviratne, S.I., Sheffield, J., Goulden, M.L., et al.: Recent decline in the global land evapotranspiration trend due to limited moisture supply. Nature, 467, 951-954. 10.1038/nature09396, 2010.

Kendall, M.G.: Rank Correlation Methods. London, England: Griffin, 10.2307/2333282, 1975.

Kochendorfer, J., Castillo, E. G., Haas, E., Oechel, W. C., Paw U, K. T.: Net ecosystem exchange, evapotranspiration and canopy conductance in a riparian forest, Agric. For. Meteorol. 151(5), 544-553, 10.1016/j.agrformet.2010.12.012, 2011.

Koster, R.D., Guo Z.C. et al. GLACE: the global land atmosphere coupling experiment. Part I: overview. J. Hydrometeorol., 7, 590-610, 10.1175/JHM510.1, 2006.

Kottek, M., Grieser, J., Beck, C., Rudolf, B., \& Rubel, F.: World map of the Koppen-Geiger climate classification updated, Meteorol. Z. 15(3), 259-263, 10.5194/hess-11-1633-2007, 2006.

Li, S., Wang, G., Sun, S., et al.: Long-term changes in evapotranspiration over China and attribution to climatic drivers during 1980-2010. Journal of Hydrology. 595(1-4):126037. 10.1016/j.jhydrol.2021.126037, 2021.

Li, S.J., Wang, G.J., Sun, S.L., Chen, H.S., et al.: Assessment of Multi-Source Evapotranspiration Products over China Using Eddy Covariance Observations. Remote Sensing, 210(11), 1692, 10.3390/rs10111692, 2018.

Liu, X., Liu, C., Luo, Y., Zhang, M., and Xia, J., et al.: Dramatic decreasing streamflow from the headwater source in the central route of China's water diversion project: Climatic variation or human influence? J. Geophys. Res. Atmos., 117, D06113, 10.1029/2011JD016879, 2011.

Loew, A., Peng, J., and Borsche, M.: High resolution land surface fluxes from satellite data (HOLAPS v1.0): evaluation and uncertainty assessment, Geoscientific Model Development, 9(7), 2499-2532, 10.5194/gmdd-8-10783-2015, 2016.

Lu, J., Wang, G., Gong, T., Hagan, D. F. T., Wang, Y., Jiang, T., \& Su, B.: Changes of actual evapotranspiration and its components in the Yangtze River valley during 1980-2014 from satellite assimilation product. Theoretical and Applied Climatology, 138, 1493-1510, 10.1007/s00704-019-02913-w, 2019.

Mann, H.B.: Nonparametric tests against trend. Econometrica, 13(3), 245-259, 1945.

Martens, B., Miralles, D.G., Lievens, H., van der Schalie, R., de Jeu, R.A.M., Fernández-Prieto, D., Beck, H.E.,Dorigo,W.A., Verhoest, N.E.C.: GLEAM v3: Satellite-based land evaporation and root-zone soil moisture. Geosci. Model Dev. 10, 19031925, 10.5194/gmd-10-1903-2017, 2017.

Martens, B., Waegeman, W., Dorigo, W. A., Verhoest, N. E. C., \& Miralles, D. G.: Terrestrial evaporation response to modes of climate variability. Npj Climate and Atmospheric Science, 1, 43, 10.1038/s41612-018-0053-5, 2018.

Massmann, A., Gentine, P., \& Lin, C.: When does vapor pressure deficit drive or reduce evapotranspiration? Journal of Advances in Modeling Earth Systems, 11, 3305-3320, 10.1029/2019MS001790, 2019.

McAdam, S. A. \& Brodribb, T. J.: The evolution of mechanisms driving the stomatal response to vapor pressure deficit. Plant Physiol, 167, 833-843, 10.1104/pp.114.252940, 2015.

Michel, D., Jiménez, C., Miralles, D.G., Jung, M., Hirschi, M., Ershadi, A., Martens, B., McCabe, M.F., Fisher, J.B., Mu, Q., et al.: TheWACMOS-ET project-Part 1: Tower-scale evaluation of four remote-sensingbased evapotranspiration algorithms. Hydrol. Earth Syst. Sci, 20, 803-822, 10.5194/hess-20-803-2016, 2016.

Miralles, D. G., Gentine, P., Seneviratne, S. I., \& Teuling, A. J.: Land-atmospheric feedbacks during droughts and heatwaves: state of the science and current challenges. Annals of the New York Academy of Sciences, 1436(1):1-17, 10.1111/nyas.13912, 2018.

Miralles, D. G., van den Berg, M. J., Gash, J. H., Parinussa, R. M., de Jeu, R. A. M., et al.: El Niño-La Niña cycle and recent trends in continental evaporation. Nature Climate Change, 4(2), 122-126, 10.1038/nclimate2068, 2013.

Miralles, D.G., de Jeu, R.A.M., Gash, J.H., Holmes, T.R.H., Dolman, A.J.: Magnitude and variability of land evaporation 
and its components at the global scale. Hydrol. Earth Syst. Sci., 15, 967-981, 10.5194/hess-15-967-2011, 2011 a.

Miralles, D.G., Holmes, T.R.H., de Jeu, R.A.M., Gash, J.H., Meesters, A.G.C.A., Dolman, A.J.: Global land-surface evaporation estimated from satellite-based observations. Hydrol. Earth Syst. Sci. 15, 453-469, 10.5194/hess-15-453-2011, $2011 b$.

5 Miralles, D.G., Jiménez, C., Jung, M., Michel, D., Ershadi, A., McCabe, M.F., Hirschi, M., Martens, B.,Dolman, A.J., Fisher, J.B., et al: The WACMOS-ET project-Part 2: Evaluation of global terrestrial evaporation data sets. Hydrol. Earth Syst. Sci., 20(2), 823-842, 10.5194/hess-20-823-2016, 2016.

Monteith, J., Unsworth, M.: Principles of Environmental Physics, 2nd ed., Edward Arnold: London, UK. 10.1088/00319112/25/2/025, 1990.

$\mathrm{Mu}$, Q., Zhao, M., Running, S.W.: Improvements to a MODIS Global Terrestrial Evapotranspiration Algorithm. Remote Sens. Environ. 115, 1781-1800, 10.1016/j.rse.2011.02.019, 2011.

Novick, K. A., Ficklin, D. L., Stoy, P. C., et al.: The increasing importance of atmospheric demand for ecosystem water and carbon fluxes. Nature Climate Change, 6(11), 1023-1027, 10.1038/nclimate3114, 2016.

Onogi, K., Tsutsui, J., Koide, H., Sakamoto, M., Kobayashi, S., Hatsushika, H., Matsumoto, T., Yamazaki, N.,Kamahori, H., Takahashi, K., et al.: The JRA-25 Reanalysis. J. Meteorol. Soc. Jpn. 85, 369-432, 10.2151/jmsj.85.369, 2007.

Pan, S., Pan, N., Tian, H., Friedlingstein, P., Sitch, S., Shi, H., Arora, V. K., Haverd, V., Jain, A. K., Kato, E., Lienert, S., Lombardozzi, D., Nabel, J. E. M. S., Ottlé, C., Poulter, B., Zaehle, S. N. \& Running, S. W.: Evaluation of global terrestrial evapotranspiration using state-of-the-art approaches in remote sensing, machine learning and land surface modeling. Hydrology and Earth System Sciences, 24, 1485-1509, 10.5194/hess-24-1485-2020, 2020.

Pan, S., Tian, H., Dangal, S. R., Yang, Q., Yang, J., Lu, C., Tao, B., Ren, W., and Ouyang, Z.: Responses of global terrestrial evapotranspiration to climate change and increasing atmospheric $\mathrm{CO} 2$ in the 21 st century, Earth's Future, 3, 15-35, 10.1002/2014EF000263, 2015.

Pascolini-Campbell, M., Reager, J. T., Chandanpurkar, H. A., \& Rodell, M.: A 10 per cent increase in global land evapotranspiration from 2003 to 2019. Nature, 593(7860), 543-547, 10.1038/s41586-021-03503-5, 2021.

Peng, J., Kharbouche, S., Muller J-P., Danne O., Blessing S., Giering R., Gobron N., Ludwig R., Muller B., Leng G., Lees T., Dadson S.: Influences of leaf area index and albedo on estimating energy fluxes with HOLAPS framework. Journal of Hydrology, 580, 124245, 10.1016/j.jhydrol.2019.124245, 2020.

Priestley, C., Taylor, R.: On the Assessment of Surface Heat Flux and Evaporation Using Large Scale Parameters. Monthly Weather Review 100(2):81-92, 10.1175/1520-0493(1972)100<0081:OTAOSH>2.3.CO;2, 1972.

Reichle, R.H., Draper, C.S., Liu, Q., Girotto, M., Mahanama, S.P.P., Koster, R.D., de Lannoy, G.J.M.: Assessment of MERRA-2 land surface hydrology estimates. J. Clim., 30, 2937-2960, 10.1175/JCLI-D-16-0720.1, 2017.

Reichle, R.H., Koster, R.D., de Lannoy, G.J.M., Forman, B.A., Liu, Q., Mahanama, S.P.P., Touré, A.: Assessment and enhancement of MERRA land surface hydrology estimates. J. Clim. 24, 6322-6338, 10.1175/JCLI-D-10-05033.1, 2011.

Rienecker, M.M., Suarez, M.J., Gelaro, R., Todling, R., Bacmeister, J., Liu, E., Bosilovich, M.G., Schubert, S.D.,Takacs, L.,

35 Kim, G.K., et al.: MERRA: NASA's Modern-Era Retrospective Analysis for research and applications. J. Clim., 24, 36243648, 10.1175/JCLI-D-11-00015.1, 2011.

Rigden, A. J., \& Salvucci, G. D.: Stomatal response to humidity and CO2 implicated in recent decline in US evaporation. Global Change Biology, 23(3), 1140-1151, 10.1111/gcb.13439, 2016.

Rodell, M., Houser, P.R., Jambor, U., Gottschalck, J., Mitchell, K., Meng, C.-J., Arsenault, K., Cosgrove, B., Radakovich, J.,

40 Bosilovich, M., et al.: The global land data assimilation system. Bull. Am. Meteorol. Soc. 85, 381-394, 10.1175/BAMS-853-381, 2004

Roderick, M. L., Sun, F., Lim, W. H., \& Farquhar, G. D.: A general framework for understanding the response of the water cycle to global warming over land and ocean. Hydrology and Earth System Sciences, 18(5), 1575-1589, 10.5194/hess-18- 
1575-2014, 2014.

Schellekens, J., Dutra, E., Martínez-de la Torre, A., Balsamo, G., van Dijk, A., et al.: A global water resources ensemble of hydrological models: The eartH2Observe Tier-1 dataset. Earth Syst. Sci. Data. 9, 389-413, 10.5194/essd-9-389-2017, 2017.

Shan, N., Shi, Z.J., Yang, X.H., Gao, J.X. Cai, D.W.: Spatio-temporal trends of reference evapotranspiration and its driving factors in the Beijing-Tianjin sand source control project Region, China. Agricultural and Forest Meteorology, 200, 322-333, 10.1016/j.agrformet.2014.10.008, 2015.

Sheffield, J., Goteti, G.,Wood, E.F.: Development of a 50-year high-resolution global dataset of meteorological forcings for land surface modeling. J. Clim., 19, 3088-3111, 10.1175/JCLI3790.1, 2006.

Sheffield, J.;Wood, E.F.; Roderick, M.L., 2012. Little change in global drought over the past 60 years. Nature, 491, 435-438, 10.1038/nature11575

Shi, Z.J., Shan, N., Xu, L.H., Yang, X.H., Gao, J.X., Guo, H., Zhang, X.,Song, A.Y. and Dong, L.S.: Spatiotemporal variation of temperature precipitation and wind trends in a desertification prone region of China from1960 to 2013. International Journal of Climatology, 36(13), 4327-4337, 10.1002/joc.4635, 2016.

Soni, A., \& Syed, T. H.: Analysis of variations and controls of evapotranspiration over major Indian River Basins (19822014). Science of The Total Environment, 754, 141892, 10.1016/j.scitotenv.2020.141892, 2021.

Sottocornola, M., Kiely, G.: Energy fluxes and evaporation mechanisms in an Atlantic blanket bog in southwestern Ireland, Water Resour. Res., 46, W11524, 10.1029/2010WR009078, 2010.

Su, B.D., Wang, A.Q., Wang, G.J., Wang, Y.J. and Jiang, T.: Spatiotemporal variations of soil moisture in the Tarim River basin, China. International Journal of Applied Earth Observation and Geoinformation, 48, 122-130, 10.1016/j.jag.2015.06.012, 2015.

$\mathrm{Su}, \mathrm{Z}$.: The surface energy balance system SEBS for estimation of turbulent heat fluxes. Hydrol. Earth. Syst. Sci,. 6, 85-99, 2002.

Sun, S., Chen, H., Ju, W., Wang, G., et al.: On the coupling between precipitation and potential evapotranspiration: Contributions to decadal drought anomalies in the Southwest China. Climate Dynamics, 48(11-12), 3779-3797, 10.1007/s00382-016-3302-5, 2017.

Sun, S., Chen, H., Wang, G., Li, J., et al.: Shift in potential evapotranspiration and its implications for dryness/wetness over Southwest China. Journal of Geophysical Research, 121(16), 9342-9355, 10.1002/2016JD025276, 2016.

Suzuk, R., Masuda, K., Dye, D.G.: Interannual covariability between actual evapotranspiration and PAL and GIMMS NDVIs of northern Asia. Remote. Sens. Environ., 106:387-398, 10.1016/j.rse.2006.10.016, 2007.

Teuling, A. J., de Badts, E. A. G., Jansen, F. A., Fuchs, R., Buitink, J., Hoek van Dijke, A. J., \& Sterling, S. M.: Climate change, reforestation/afforestation, and urbanization impacts on evapotranspiration and streamflow in Europe. Hydrology and Earth System Sciences, 23(9), 3631-3652, 10.5194/hess-23-3631-2019, 2019.

Trenberth, K. E., Smith, L., Qian, T., Dai, A., Fasullo, J.: Estimates of the global water budget and its annual cycle using observational and model data. J. Hydrometeorol. 8, 758-769, 10.1175/JHM600.1, 2007.

Vinukollu, R. K., Meynadier, R., Sheffield, J., \& Wood, E. F.: Multi-model, multi-sensor estimates of global evapotranspiration: climatology, uncertainties and trends. Hydrological Processes, 25(26), 3993-4010, 10.1002/hyp.8393, 2011.

Wang, G.J., Pan, J., Shen, C.C., Li, S.J., Lu, J., Lou, D., Hagan, D. F. T., et al.: Evaluation of Evapotranspiration Estimates in the Yellow River Basin against the Water Balance Method. Water, 10(12), 1884, 10.3390/w10121884, 2018a.

40 Wang, G.J., Gong, T.T., Lu, J., Lou, D., Hagan, D.F.T. and Chen, T.X.: On the long-term changes of drought over China (1948-2012) from different methods of PET estimations. International Journal of Climatology, 38(7), 2954-2966, 10.1002/joc.5475, 2018 b.

Wang, K.C., Dickinson, R.E.: A review of global terrestrial evapotranspiration: observation, modeling, climatology, and 
climatic variability. Reviews of Geophysics, 50(RG2005), 1-54, 10.1029/2011RG000373, 2012.

Wang, K.C., Dickinson, R.E., Wild, M., Liang, S.L.: Evidence for decadal variation in global terrestrial evapotranspiration between 1982 and 2002: 2. Results. J. Geophys. Res. Atmos., 2010, 115, D20113, 10.1029/2010JD013847, 2010.

Wang, Y., Liu, B., Su, B., Zhai, J., \& Gemmer, M.: Trends of Calculated and Simulated Actual Evaporation in the Yangtze River Basin. Journal of Climate, 24(16), 4494-4507, 10.1175/2011JCLI3933.1, 2011.

Weedon, G.P., Balsamo, G., Bellouin, N., Gomes, S., Best, M.J., Viterbo, P.: The WFDEI meteorological forcing data set: WATCH Forcing Data methodology applied to ERA-Interim reanalysis data. Water Resour. Res. 50, 7505-7514, 10.1002/2014WR015638, 2015.

Wilcox, R.R.: Fundamentals of modern statistical methods: substantially improving power and accuracy. Springer New York, 319(5862), 153-154, 2010.

Wu, P., Christidis, N. \& Stott, P.: Anthropogenic impact on Earth's hydrological cycle. Nature Climate Change, 3, 807-810, 10.1038/nclimate1932, 2013.

Xu, X., Liu, W., Scanlon, B. R., Zhang, L., \& Pan, M.: Local and global factors controlling water-energy ba-lances within the Budyko framework. Geophysical Research Letters, 40, 6123-6129, 10.1002/2013GL058324, 2013.

Yang, D., Shao, W., Yeh, P. J. F., Yang, H., Kanae, S., Oki, T.: Impact of vegetation coverag-e on regional water balance in the nonhumid regions of China, Water Resour. Res., 45, W00A14. 0.1029/2008WR006948, 2009.

Yang, H., Yang, D., Lei, Z., Sun, F.: New analytical derivation of the mean annual water-energy balance equation. Water Resour Res., 44, W03410, 10.1029/2007WR006135, 2008.

Yang, Y., Roderick, M. L., Zhang, S., McVicar, T. R., \& Donohue, R. J.: Hydrologic implications of vegetation response to elevated CO2 in climate projections. Nature Climate Change, 9, 44-48, 10.1038/s41558-018-0361-0, 2019.

Yokoo, Y., Sivapalan, M., Oki, T.: Investigating the roles of climate seasonality and landscape characteristics on mean annual and monthly water balances, J. Hydrol. 357, 255-269, 10.1016/j.jhydrol.2008.05.010, 2008.

Zeng, R., and X. Cai.: Climatic and terrestrial storage control on evapotranspiration temporal variability: Analysis of river basins around the world, Geophys. Res. Lett. 43, 185-195, 10.1002/2015GL066470, 2016.

Zhang, K., Kimball, J. S., Nemani, R. R., Running, S. W., Hong, Y., Gourley, J. J., \& Yu, Z.: Vegetation Greening and Climate Change Promote Multidecadal Rises of Global Land Evapotranspiration. Scientific Reports, 5, 1595, 10.1038/srep15956, 2015.

Zhang, K., Kimball, J.S., Running, S.W.: A review of remote sensing based actual evapotranspiration estimation. Wiley Interdiscip. Rev. Water. 3, 834-853, 10.1002/wat2.1168, 2016.

Zhang, L., K. Hickel, W. R. Dawes, F. H. S. Chiew, A. W. Western, and P. R. Briggs.: A rational function approach for estimating mean annual evapotranspiration, Water Resour. Res., 40, W02502, 10.1029/2003WR002710, 2004.

Zhang, Q., Yang, Z., Hao, X. et al.: Conversion features of evapotranspiration responding to climate warming in transitional climate regions in northern China. Clim. Dyn., 52, 3891, 10.1007/s00382-018-4364-3, 2019.

Zhou, J., Wang, Y., Su, B., Wang, A., Tao, H., Zhai, J. et al.: Choice of potential evapotranspiration formulas influences drought assessment: A case study in China. Atmospheric Research, 104979, 10.1016/j.atmosres.2020.104979, 2020. 